Pesq. Vet. Bras. 29(12):959-962, dezembro 2009

\title{
Occurrence of parasitism by Dioctophyma renale in ring- tailed coatis (Nasua nasua) of the Tiete Ecological Park, São Paulo, Brazil ${ }^{1}$
}

\author{
Liliane Milanelo ${ }^{2}$, Márcia Bento Moreira ${ }^{3}$, Lílian S. Fitorra², Bruno S.S. Petri², \\ Melissa Alves ${ }^{2}$ and Aparecida de Cássia dos Santos ${ }^{4}$
}

\begin{abstract}
Milanelo L., Moreira M.B., Fitorra L.S., Petri B.S.S., Alves M. \& Santos A.C. 2009. Occurrence of parasitism by Dioctophyma renale in ring-tailed coatis (Nasua nasua) of the Tiete Ecological Park, São Paulo, Brazil. Pesquisa Veterinária Brasileira 29(12):959-962. Centro de Recuperação de Animais Selvagens, Parque Ecológico do Tietê, Departamento de Águas e Energia Elétrica, Rua Guira Acangatara 70, Engenheiro Goulart, São Paulo, SP 03719-000, Brazil. E-mail: Imilanelo@gmail.com

Dioctophymosis is a worldwide renal parasitosis caused by the Dioctophyma renale nematode, which results in progressive destruction of renal tissue. Aquatics annelids are considered the main intermediate hosts and the literature refers as permanent hosts of dogs, wild mammals and even humans. During procedures for population control of coatis (Nasua nasua) in the Ecological Park of Tietê (PET), was noticed the presence of parasitosis by $D$. renale. From 68 animals, males and females, young and adults, submitted to exploratory laparotomy, 51 were positive for the presence of worms, 9 were found only in the right kidney. In 10 cases, in addition to right kidney parasitism, worms were also observed in the abdominal cavity. In 24 cases $D$. renale was found only in the abdominal cavity and in 8 animals the right kidney was reduced to a small rigid structure. The study showed that the preferred site for parasitism of the worm, considered erratic, was the abdominal cavity in $66.66 \%$ of the cases.
\end{abstract}

INDEX TERMS: Dioctophyma renale, Nasua nasua, parasitismo, dioctophymosis.

RESUMO.- [Ocorrência de parasitismo por Dioctophyma renale em quati (Nasua nasua) do Parque Ecológico Tietê, São Paulo.] A dioctofimose é uma parasitose renal causada pelo nematóide Dioctophyma renale conhecida por gerar a destruição progressiva do parênquima renal. Anelídeos de água doce são considerados os principais hospedeiros intermediários e a literatura refere como hospedeiros definitivos cães domésticos, mamíferos selvagens e até seres humanos. Durante procedimentos de controle populacional de quatis (Nasua nasua) no Parque

\footnotetext{
${ }^{1}$ Received on October 18, 2008.

Accepted for publication on June 16, 2009

${ }^{2}$ Centro de Recuperação de Animais Selvagens, Parque Ecológico do Tietê, Departamento de Águas e Energia Elétrica (CRAS-PET/DAEE), Rua Guira Acangatara 70, Engenheiro Goulart, São Paulo, SP 03719000, Brazil. *Corresponding author: Imilanelo@gmail.com

3 Universidade Federal do Vale do São Francisco (Univasf), Av. José de Sá Manissoba s/n, Campos Universitário, Petrolina, PE 56304-205, Brazil.

${ }^{4}$ Médica Veterinária Autônoma, Instituto Vetimagem, Rua Pedro Madureira 322, Jardim São Paulo, SP 02044-140.
}

Ecológico do Tietê (PET), evidenciou-se a presença do parasitismo por $D$. renale. Sessenta e oito animais foram submetidos à laparotomia, machos e fêmeas, jovens e adultos, dos quais 51 foram positivos para presença do parasita. Em 9 animais o parasita esteve presente apenas no rim direito; em 10 animais $D$. renale parasitava o rim direito e a cavidade abdominal simultaneamente. Em outros 24 quatis o parasita foi encontrado apenas na cavidade abdominal e em 8 animais o rim direito foi reduzido apenas a uma pequena estrutura rígida. $O$ estudo demonstrou que para este hospedeiro (Nasua nasua), o rim direito não parece ser local de escolha do parasita, já que o encontro do verme em $66,6 \%$ dos casos foi a cavidade abdominal.

TERMOS DE INDEXAÇÃO: Dioctophyma renale, Nasua nasua, parasitismo, dioctofimose.

\section{INTRODUCTION}

Dioctophymosis is a worldwide renal parasitosis caused by the Dioctophyma renale nematode, which generates the progressive destruction of the kidney, reducing the organ 
to a fibrous capsule (Leite et al. 2005). The parasite is almost always found in the right kidney (Fernando 1983, Kommers et al. 1999, Kano et al. 2003, Leite et al. 2005,), but may also erratically live in the peritoneal cavity, urinary vesicle (Nakagawa et al. 2007) and even in the stomach (Miranda et al. 2007). With indirect life cycle, $D$. renale affects domestic mammals, especially dogs (Kommers et al. 1999, Nakagawa et al. 2007), wild carnivorous and even humans as permanent hosts through the ingestion of contaminated intermediate or paratenic hosts (annelids, fresh water fishes and/or frogs) (Measures \& Andersons 1985, Mayrink et al. 2000).

In Brazil, parasitism by $D$. renale has been described in wild animals such as ferrets (Galictis cuja), maned wolf (Crysocyon brachyurus), sloths (Choloepus didactylus), otters (Lutra longicaudis), bush dogs (Speothos venaticus) (Kommers et al. 1999) and coatis (Nasua nasua) (Milanelo et al. 2003, Castro et al. 2004, Milanelo et al. 2007). The incidence of dioctophymosis in animals is related to their access to aquatic environments (Kano et al. 2003) and to their feeding habits (Santos \& Beisiegel 2006), associated to the parasite's life cycle (Kano et al. 2003).

Coatis (Carnivora, Procyonidae) used in this study are primarily omnivorous, their social organization shows juvenile females and males live in groups of up to 30 individuals and males as from 2 years of age are solitaire (Gompper \& Decker, 1998). Nearly 10 groups of N. nasua, with around 20 to 30 individuals each, live in semi-captivity situation, inhabiting an area in the Tietê River bank made up by the Ecologic Park (PET) in São Paulo city.

\section{MATERIALS AND METHODS}

During procedures for population control of coatis (Nasua nasua), through ovariosalpingo-hysterectomy $(\mathrm{OSH})$ of females and vasectomy of males, was noticed the presence of cylindrical reddish worms, $20-80 \mathrm{~cm}$ long and $0.3-1.0 \mathrm{~cm}$ diameter, single or in larger quantities free in the abdominal cavity or wrapped by the right renal capsule in females during $\mathrm{OSH}$, fact that has brought up the need for exploratory laparotomy in males to look for Dioctophyma renale, the objective of this research to report the occurrence of the parasitism in PET coatis.

Samples. Sixty-eight coatis (Nasua nasua), males and females, young and adults, weighing $1.2-7.0 \mathrm{~kg}$, from the semicaptivity system of the Tietê Ecological Park, were submitted to population control procedures.

Anesthesia. The animals were anesthetized with $10 \mathrm{mg} / \mathrm{kg}$ deep intramuscular tiletamine and zolazepan injection, associated in the same syringe with $4 \mathrm{mg} / \mathrm{kg}$ tramadol.

Surgical procedure. After anesthesia, all animals received electronic marking (microchip) and were submitted to exploratory laparotomy to look for $D$. renale, followed by ovariosalpingohysterectomy $(\mathrm{OSH})$ in females and vasectomy through the abdominal cavity in males.

Urine parasitological exam. To confirm the parasite species, urine was collected by cystocentesis for posterior parasitological exam. (Castro et al, 2004)

\section{RESULTS}

Surgical procedure. During exploratory laparotomy, we noticed the presence of reddish cylindrical worms, $20-80 \mathrm{~cm}$

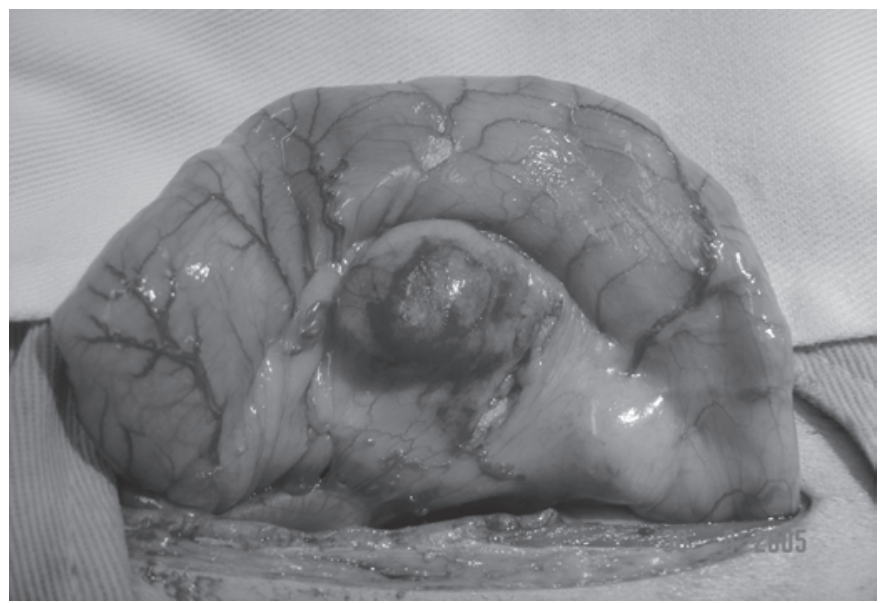

Fig.1. Right kidney parasited by Dioctophyma renale.

long and $0.3-1.0 \mathrm{~cm}$ diameter, characterized morphologically by well-developed multipolar cells connecting the body wall and the intestine, 8 longitudinal striae, and the presence of a caudal bursa in males (Koehler et al, 2009), single or in larger quantities, free in the abdominal cavity or wrapped by the right renal capsule (Fig.1).

Urine parasitological exam. It was possible to isolate eggs and to identify them as Dioctophyma renale eggs in variable quantities and different maturation periods (Fig.2).

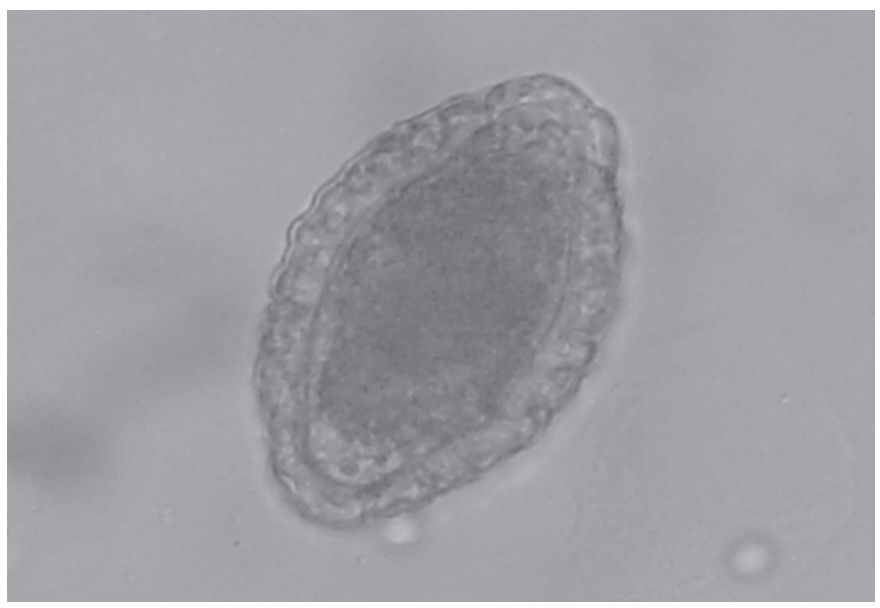

Fig.2. Egg of Dioctophyma renale (10x).

Coatis were clinically healthy, without suggestive signs of parasitism, however 51 (75\%) of the 60 Nasua nasua submitted to laparotomy were positive for the presence of $D$. renale, among them 20 males and 31 females, with ages varying from 6 -month-old ones with $1.2 \mathrm{~kg}$ to adults weighing up to $7 \mathrm{~kg}$.

From 51 positive coatis, in 9 animals $D$. renale was found, together with embryonic or non embryonic eggs in the urine, only in the right kidney, where frequently a single coiled female worm was covered only by the renal capsule, as the whole parenchyma was consumed (Fig.3). In two $(2 / 9)$ cases there was just a couple of $D$. renale inside the renal capsule. 


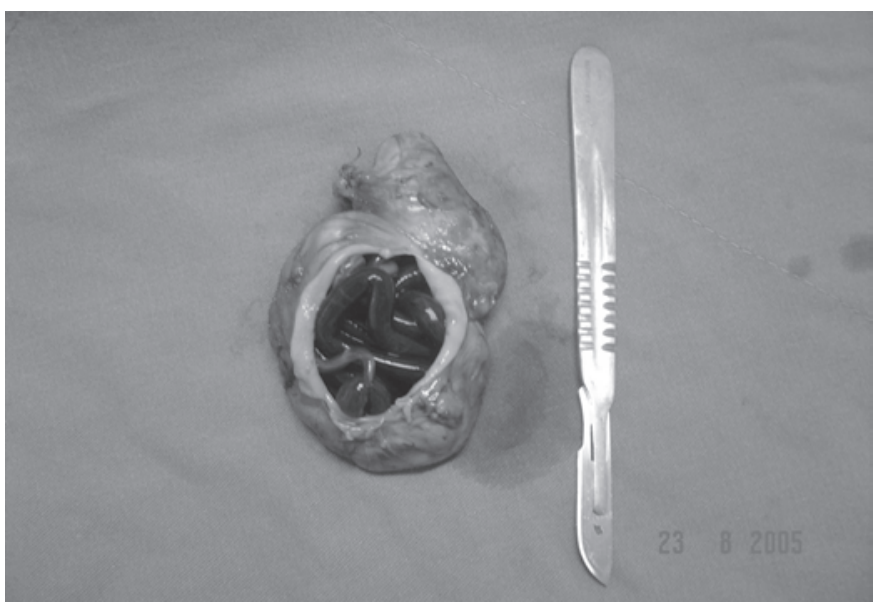

Fig.3. Parasited right kidney after unilateral nefrectomy.

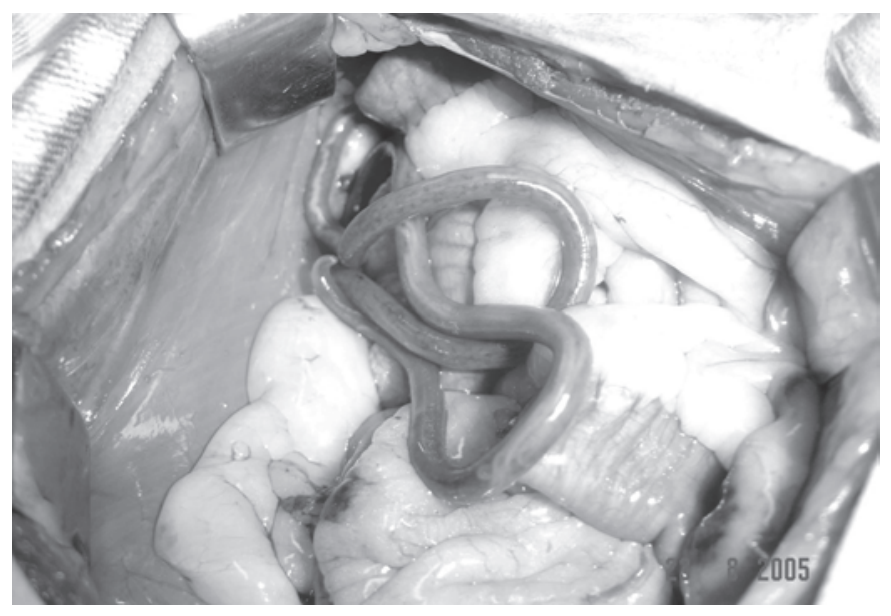

Fig.4. Free Dioctophyma renale in the abdominal cavity.

In 10 cases, in addition to right kidney parasitism, were also observed free worms in the abdominal cavity, lodged close to the liver parenchyma (Fig.4), in numbers of 1-5 females and males, always with the predominance of males.

In 24 cases were only found free $D$. renale in the abdominal cavity, predominantly close to the liver parenchyma. In these cases there were holes in the mesentery and nodular brownish injuries of firm consistency, with 0.5 $3.0 \mathrm{~cm}$ diameter in the epiploon, mesentery or stomach wall (Fig.5).

Eight coatis $(8 / 51)$ had their right kidney totally destroyed and the capsule reduced to a small $2 \mathrm{~cm}$ wide rigid structure.

The contralateral kidney of affected animals had variable size, however almost always compatible with those of animals not infested by the parasite. Contralateral kidney hystopathological analysis of an animal which died during physical contention revealed multifocal, chronic interstitial nephritis and tubular degeneration.

Gross findings. All positive animals had signs of fetid odor peritonitis, with slight serum-bloody secretion,

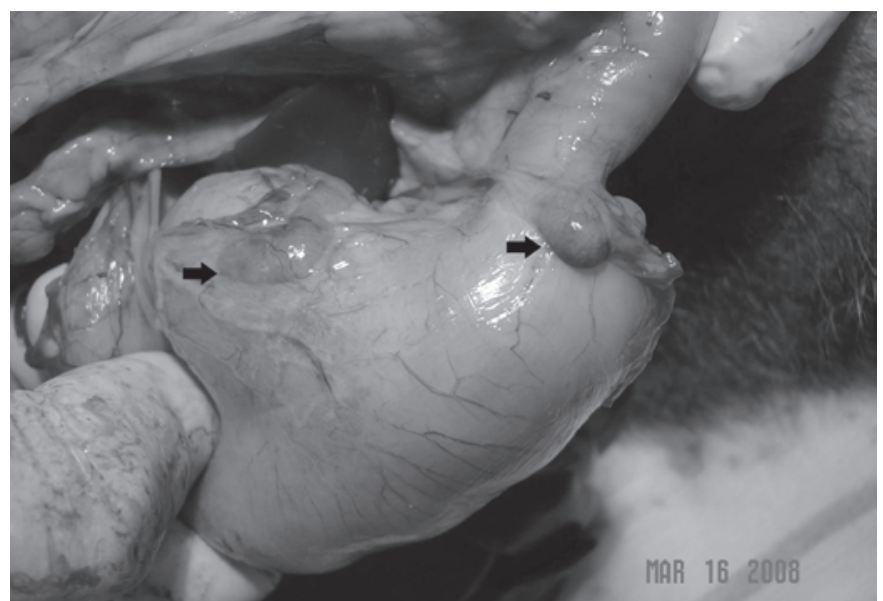

Fig.5. Nodules in gastric serosa.

brownish epiploon with friable consistency, liver surface with whitish points and adherence areas with deposition of rusty filamentous material, also present on the servos of intestinal loops, as well as major lymphatic congestion.

\section{DISCUSSION}

According to Silva \& Lima (2004), although the Nasua nasua species is widely distributed and relatively common in the country, pathology of the species is still poorly studied, and this finding appears to be first report on the subject.

The site where these cases were described, Tietê River bank, is in line with the literature (Kano 2003), i.e., the parasitosis is associated with the presence of abundant water, considering parasite life cycle.

The literature refers a lot of single case reports for the parasitism of Dioctophyma renale and few researches of contaminated population.

Mech \& Shawn (2001) found $27 \%$ of prevalence on 138 carcasses of Mustela vison in Minnesota, USA; as Kommers 1999 in a retrospective survey of dogs necropsy data in Rio Grande do Sul, related $0.49 \%$ of parasitic prevalence by $D$. renale. However the prevalence in Nasua nasua is $75 \%$, explained by the high animal density in the same area.

Kommers (1999) and Mech \& Shawn (2001), describe the prevalence of right renal parasitism, where only 3 of 16 dogs and 18 of $138 \mathrm{M}$. vison were parasitized only in the right kidney, while the findings of this research showed parasitism of the abdominal cavity in $66.6 \%$ positives coatis, suggesting a differential pattern of parasite in Nasua nasua.

In this research there was no significant difference in the prevalence of the parasite between males and females of coatis, as observed by Mech \& Shawn (2001) in minks.

Although Nasua nasua does not have the habit to swim, thus decreasing the possibility to be contaminated by the ingestion of the intermediate host (e.g. contaminated fishes or annelids).

According to Nakagawa et al. (2007), the presence of the parasite in the abdominal cavity is considered erratic, 
however, for this host, the worm's preferred site was the abdominal cavity, as in $66.66 \%$ of the cases the parasite was found free in the abdominal cavity, close to the liver border.

\section{CONCLUSION}

There is the imminent need of determining the epidemiological cycle of this parasitic disease inside PET, so that actions to control and/or treatment could be taken, because in spite of the low zoonotic potential, humans may be accidentally inserted in the nematode Dioctophyma renale cycle.

Acknowledgements.- To the Tietê Ecological Park Management for the financial support.

\section{REFERENCES}

Castro J.M., Santos S.V., Milanelo L. \& Godoy S.N. 2004. Ocorrência de Dioctophyma renale em quatis Nasua nasua do Parque Ecológico Tietê, São Paulo, Brasil. 25ํㅡㄹ Congresso Brasileiro de Zoologia. Brasília.

Fernando S.S. 1983. The giant kidney worm (Dioctophyma renale) infection in man in Australia. Am. J. Surg. Pathol. 7(3):281-284.

Gompper M.E. \& Decker D.M. 1998. Nasua nasua. Mammalian Species 580:1-9.

Kano F.S., Shimada M.T., Suzuki S.N., Osaka S.C., Menarim B.C., Ruthes F.R.V. \& Filho M.A.L. 2003. Ocorrência de dioctofimose em dois cães no município de Guarapuava, PR. Revta Ciênc. Agrárias 24(1):177-180.

Kommers G.D., Ilha M.R.S. \& Barros C.S.L. 1999. Dioctofimose em cães: 16 casos. Ciência Rural 29(3):517-522.

Leite, L.C., Círio S.M., Diniz J.M.F., Navarro-Silva M.A., Silva A.W.C.,
Leite S.C., Zadorosnei A.C., Musiat K.C., Veronesi E.M. \& Pereira C.C. 2005. Lesões anatomopatológicas presentes na infecção por Dioctophyma renale (Goeze, 1782) em cães domésticos (Canis familiaris, Linnaeus, 1758). Arch. Vet. Sci. 10(1):95-101.

Mayrink K.C., Paes-de-Almeida E.C. \& Thomé S.M.G. 2000. Dioctophyma renale (Goeze, 1782) em cães. Cad. Téc. Cient. Esc. Med. Vet., Univ. Grande Rio, 2:20-40.

Measures L.N. \& Andersons R.C. 1985. Centrarchid fish as paratenic hosts of the giant kidney worm, Dioctophyma renale (Goeze, 1782), in Ontario, Canada. J. Wildl. Dis. 21(1):11-19.

Milanelo L., Toledo A.P.C., Godoy S.N., Craveiro C.F., Penteado F.A. \& Pinto I.T. 2003. Dioctophyma renale em quati (Nasua nasua): relato de caso. Anais $7^{\circ}$ Congresso e $12^{\circ}$ Encontro da Abravas, São Pedro, SP.

Milanelo L., Moreira M.B., Calil B.E.M., Santos A.C., Santos L.H., Alves M. 2007. Menez J.F.Q.M. Diagnóstico ultra-sonográfico de Dioctofimose em quatis (Nasua nasua): 17 casos. Anais $31^{\circ}$ Congr. Soc. Zoológicos do Brasil, 15ำ Congr. Assoc. Latinoam. Parques Zoológicos e Aquários e 15ํㅡㄹ Encontro Assoc. Bras. Vet. Anim. Selvagens, São Paulo, SP, p.291.

Miranda M.A., Benigno R.N.M., Galvão G.R. \& Oliveira S.A.L. de 1992. Dioctophyme renale (Goeze, 1782): localização ectópica e alta intensidade parasitária em Canis familiaris do Pará, Brasil. Arq. Bras. Med. Vet. Zootec. 44(2):151-153.

Nakagawa T.L.D.R., Bracarense A.P., dos Reis A.C., Yamamura M.H. \& Headley AS. 2007. Giant kidney worm (Dioctophyma renale) infections in dogs from northern Paraná, Brazil. Vet. Parasitol. 145(3/ 4):366-370.

Santos V.A. \& Beisiegel B.M. 2006. Comunicação Científica: a dieta de Nasua nasua (Linnaeus, 1766) no Parque Ecológico do Tietê, SP. Revta Bras. Zoociênc. 8(2):199-203.

Seville R.S. \& Addison E.M. 1995. Nongastrointestinal helmints in marten (Martes americana) from Ontario, Canada. J. Wildl. Dis. 31(4):529533. 